Article

\title{
Elucidation of oxygen reduction reaction pathway on carbon-supported manganese oxides
}

\author{
Luhua Jiang a,*, Qiwen Tang a,b, Jing Liu a,b, Gongquan Sun a,\# \\ a Dalian Institute of Chemical Physics, Chinese Academy of Sciences, Dalian 116023, Liaoning, China \\ ${ }^{\mathrm{b}}$ University of Chinese Academy of Sciences, Beijing 100049, China
}

\section{A R T I C L E I N F O}

Article history:

Received 30 September 2014

Accepted 10 November 2014

Published 20 February 2015

\section{Keywords:}

Oxygen reduction reaction pathway

Alkaline electrolyte

Carbon-supported electrocatalyst

Manganese oxide

\begin{abstract}
A B S T R A C T
The oxygen reduction reaction (ORR) is a complex process. This is particularly the case for carbon-supported electrocatalysts in alkaline electrolytes, because carbon can catalyze the ORR via a two-electron transfer to generate hydroperoxide $\left(\mathrm{HO}_{2}^{-}\right)$, which subsequently undergoes either chemical decomposition to generate $\mathrm{O}_{2}$ and $\mathrm{OH}^{-}$(HODR) or electrochemical reduction to $\mathrm{OH}^{-}$ (HORR). In this study, we elucidated the ORR pathway on a series of carbon-supported manganese oxides, which have been extensively studied as electrocatalysts in alkaline electrolytes. A comparison of the turnover frequencies of the HODR and HORR showed that although an apparent four-electron transfer process was identified when the $\mathrm{HO}_{2}^{-}$yield was measured using the rotating ring disk electrode technique, the real ORR pathway involved a two-electron transfer process to generate $\mathrm{HO}_{2}^{-}$, with subsequent chemical decomposition of $\mathrm{HO}_{2}{ }^{-}$. These results will help us to understand the intrinsic catalytic behavior of carbon-supported transition-metal oxides for the ORR in alkaline electrolytes.
\end{abstract}

(C) 2015, Dalian Institute of Chemical Physics, Chinese Academy of Sciences. Published by Elsevier B.V. All rights reserved.

\section{Introduction}

The oxygen reduction reaction (ORR) is very important because it is the cathodic reaction in fuel cells and metal-air batteries. Pt-based materials are extensively used as ORR catalysts under acidic conditions, but under alkaline conditions, a wide range of non-noble metals and their oxides are stable and active for practical applications [1-3]. An understanding of the ORR pathway on a catalyst surface is critical in both fundamental and practical terms. Although the ORR pathway on a smooth catalyst surface can be easily studied using the rotating ring disk electrode (RRDE) technique, for a carbon-based prac- tical porous electrode, the ORR pathway is complex because the considerable amount of intermediate $\mathrm{HO}_{2}{ }^{-}$generated at the carbon surface can be readsorbed for further reactions. Specifically, hydroperoxide species have three possible subsequent pathways, as shown in Scheme 1, i.e., (1) diffusion directly into the electrolyte as a product, (2) further electrochemical reduction to form $\mathrm{OH}^{-}$, and (3) chemical decomposition to produce $\mathrm{O}_{2}$ and $\mathrm{OH}^{-}$. Unlike case (1), cases (2) and (3) are apparent four-electron processes, although only case (2) is a real four-electron process. Our previous study of carbon-supported cobalt oxides $[4,5]$ clearly showed that although the apparent electron transfer number was close to four in a large potential

\footnotetext{
* Corresponding author. Tel: +86-411-84379603; Fax: +86-411-84379063; E-mail: sunshine@dicp.ac.cn

\# Corresponding author. Tel: +86-411-84379603; Fax: +86-411-84379063; E-mail: gqsun@dicp.ac.cn

This work was supported by the Strategic Priority Research Program of Chinese Academy of Sciences (XDA09030104), the National Basic Research Program of China (973 Program, 2012CB215500), the National Natural Science Foundation of China (21033009), and the 100-Talent Program of Chinese Academy of Sciences. DOI: 10.1016/S1872-2067(14)60249-7 | http://www.sciencedirect.com/science/journal/18722067 | Chin. J. Catal., Vol. 36, No. 2, February 2015
} 


\section{$k_{4}\left(4 \mathrm{e}^{-}\right)$, direct $4 \mathrm{e}^{-}$pathway}

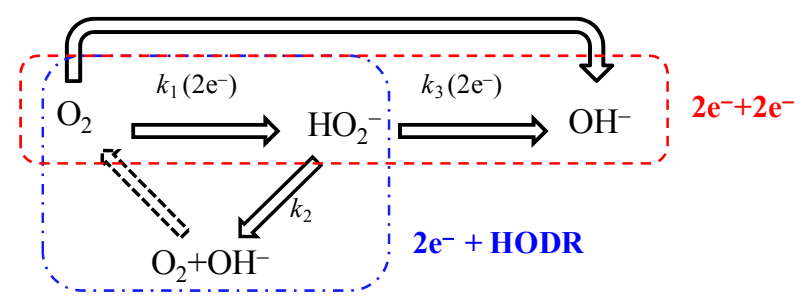

Scheme 1. Various possible mechanisms for $\mathrm{O}_{2}$ reduction in alkaline solution.

window, different electrochemical reactions occurred depending on the electrode potential, i.e., a two-electron transfer process followed by chemical decomposition of hydroperoxide at low overpotentials, but two-electron transfer followed by further electrochemical reduction of hydroperoxide, namely a serial four-electron transfer process, at high overpotentials.

Other promising transition-metal oxides, e.g., manganese oxides, are also worth investigating to help us to understand catalysis of the ORR by transition-metal oxides. Previously, it was concluded that a two-electron transfer process with subsequent chemical decomposition of hydroperoxide occurred on a manganese oxide surface [6,7]. However, there is still a lack of experimental evidence to support this deduction. In this paper, continuing our previous study on the effects of manganese valences in manganese oxides on ORR activity [8], we aim to elucidate the ORR pathway on carbon-supported manganese oxides. The manganese oxide samples used in this study are the same as those used in our previous study [8]; therefore, the preparation procedures will not be described again. First, we calculated the electron transfer number of the ORR according to the Koutecky-Levich equation by measuring the ORR polarization curves via the rotating disk electrode (RDE) technique. We then distinguished between direct and indirect four-electron transfer processes by detecting the $\mathrm{HO}_{2}{ }^{-}$yields at manganese oxides of different catalyst thicknesses via the RRDE technique. Finally, we determined the main reactions in peroxide chemical decomposition (HODR) and electrochemical reduction (HORR) by measuring the turnover frequencies (TOFs) of the two reactions.

\section{Experimental}

\subsection{Experimental setup}

A traditional three-electrode system was used for RDE and RRDE measurements. The RDE ( $\Phi 5 \mathrm{~mm}$, glassy carbon (GC)] measurements were performed using a CHI 760D electrochemical workstation. The RRDE measurements were performed using a Bi-potentiostat (Pine Instruments). GC covered by a porous catalyst film was used as the working electrode, and $\mathrm{Pt}$ wire and a $\mathrm{Hg} / \mathrm{HgO}$ electrode (MMO, in $1 \mathrm{~mol} / \mathrm{L} \mathrm{NaOH}$, $0.93 \mathrm{~V}$ vs reversible hydrogen electrode after calibration) served as the counter and reference electrodes, respectively. The potential of the Pt ring electrode was kept at $0.2 \mathrm{~V}$ vs the MMO during the RRDE tests.

\subsection{Working electrode preparation}

The preparation of the working electrode has been described in detail in the literature [9]. Briefly, catalyst powder (3 $\mathrm{mg}$ ) was dispersed in ethanol (2 $\mathrm{mL}$ ). Carbon powder (2 mg; Vulcan XC-72, Cabot Corp.) was added to increase the conductivity, and $5 \mathrm{wt} \%$ Nafion solution ( $50 \mu \mathrm{L}$; DuPont) was added as a binder. The mixture was ultrasonicated to form a well-dispersed ink. A certain amount of the ink was pipetted onto the GC electrode and then the solvent was evaporated at room temperature to form a catalyst thin film. All the $\mathrm{MnO}_{x}$ catalyst samples were fresh, without any electrochemical pretreatment.

\subsection{Determination of ORR and HORR polarization curves}

The ORR and HORR polarization curves were recorded in $\mathrm{O}_{2}$-saturated $1 \mathrm{~mol} / \mathrm{L} \mathrm{NaOH}$ solution and $\mathrm{N}_{2}$-saturated $1 \mathrm{~mol} / \mathrm{L}$ $\mathrm{NaOH}$ containing $0.85 \mathrm{mmol} / \mathrm{L} \mathrm{H}_{2} \mathrm{O}_{2}$ solution, respectively, at a scanning rate of $10 \mathrm{mV} / \mathrm{s}$.

\subsection{TOF measurements (HODR)}

GC covered with a Pt/C catalyst was used as a probe to detect the changes with time in the $\mathrm{H}_{2} \mathrm{O}_{2}$ concentration in the electrolyte after adding $\mathrm{MnO}_{x}$ as the HODR catalyst. The measurements were also carried out in a three-electrode system [10]. The preparation procedure for the thin-film electrode with $\mathrm{Pt} / \mathrm{C}$ as the electrocatalyst was the same as that described above for the $\mathrm{MnO}_{x}$ electrode. After electrochemically cleaning the electrode surface at a scanning rate of $100 \mathrm{mV} / \mathrm{s}$ in $1 \mathrm{~mol} / \mathrm{L}$ $\mathrm{NaOH}$, the ORR limiting current $\left(i_{\mathrm{lim}, \mathrm{ORR}}\right)$ was recorded by holding the electrode potential at $-0.5 \mathrm{~V}$ for $10 \mathrm{~s}$, with the electrode rotating at a speed of $1600 \mathrm{rpm}$. Then $\mathrm{H}_{2} \mathrm{O}_{2}$ (30\%) was added to the electrolyte to ensure a concentration of $0.85 \mathrm{mmol} / \mathrm{L}$ (the same concentration as that of $\mathrm{O}_{2}$ in the $\mathrm{O}_{2}$-saturated 1 mol/L NaOH solution) [11]. Then $\mathrm{MnO}_{x}(300 \mu \mathrm{g})$ dispersed in water $(1 \mathrm{~mL})$ was quickly added to the $\mathrm{H}_{2} \mathrm{O}_{2}$-containing electrolyte under magnetic stirring to ensure good contact of the $\mathrm{MnO}_{x}$ catalyst with $\mathrm{H}_{2} \mathrm{O}_{2}$. The Pt electrode was held at $-0.5 \mathrm{~V}$ for $10 \mathrm{~s}$ to collect the current ( $\left.i_{\text {lim }}\right)$ at intervals. The concentration of residual $\mathrm{HO}_{2}{ }^{-}$in the electrolyte could be calculated according to the current difference on the Pt electrode $\left(i_{\mathrm{lim}, \mathrm{HORR}}=i_{\mathrm{lim}}-\right.$ $i_{\text {lim,ORR }}$. The measurements continued for only $10 \mathrm{~s}$ at each interval and then the Pt electrode was rapidly removed from the electrolyte after the tests, therefore it was assumed that no extra $\mathrm{HO}_{2}^{-}$decomposed at the Pt surface.

\section{Results and discussion}

\subsection{Measurement of ORR electron transfer numbers of carbon-supported manganese oxide electrocatalysts}

The ORR polarization curves of the carbon-supported manganese oxide electrocatalysts were measured in $\mathrm{O}_{2}$-saturated 1 mol/L NaOH electrolyte; the results are shown in Fig. 1. The ORR onset potentials of the four carbon-supported $\mathrm{MnO}_{x}$ catalysts with different manganese valences, i.e., $\mathrm{MnOOH} / \mathrm{Mn}(\mathrm{OH})_{4}$, 


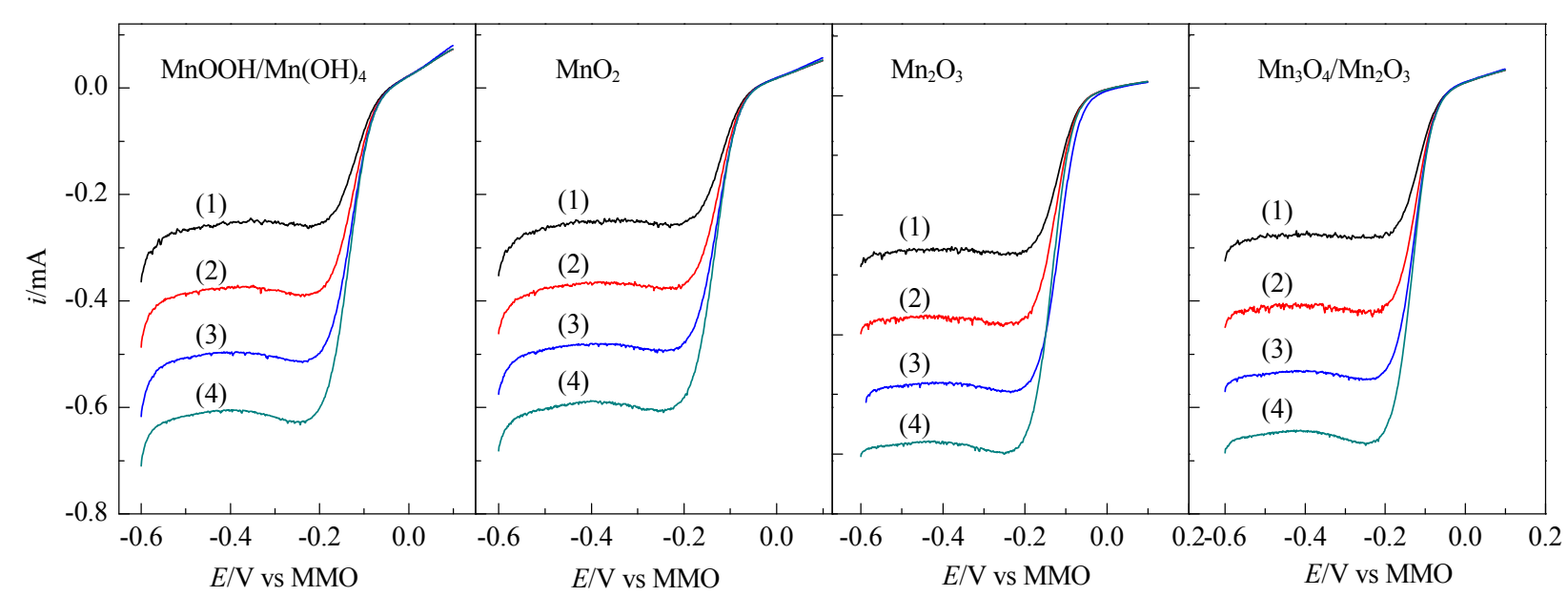

Fig. 1. ORR polarization curves for $\mathrm{MnO}_{x}+\mathrm{C}$ catalysts at different rotation rates. (1) $400 \mathrm{rpm}$; (2) $900 \mathrm{rpm}$; (3) $1600 \mathrm{rpm}$; (4) $2500 \mathrm{rpm}$.

$\mathrm{MnO}_{2}, \mathrm{Mn}_{2} \mathrm{O}_{3}$, and $\mathrm{Mn}_{3} \mathrm{O}_{4} / \mathrm{Mn}_{2} \mathrm{O}_{3}$ [8], are very similar, and the ORR limiting currents increase with increasing electrode rotating rate. For comparison, the ORR limiting current with Vulcan ${ }^{\circledR}$ XC-72 carbon as the electrocatalyst is lower than that with $\mathrm{MnO}_{x}$. According to the Koutecky-Levich equation [12]:

$$
i_{\mathrm{lim}}=0.62 n F A D_{\mathrm{o}}{ }^{2 / 3} \omega^{1 / 2} v^{-1 / 6} C_{\mathrm{o}}{ }^{*}
$$

(where $n$ is the ORR electron transfer number, $F$ is the Faraday constant, $A$ is the geometric area of the electrode, $D$ is the diffusion coefficient of $\mathrm{O}_{2}$ in the electrolyte, $\omega$ is the rotation speed of the electrode in radians, $v$ is the viscosity of the electrolyte, and $C_{0} *$ is the concentration of $\mathrm{O}_{2}$ at the electrode surface), the limiting current is proportional to the square root of the electrode rotating rate, therefore the relationship between $1 / i_{\text {lim }}$ and $\omega^{-0.5}$ (@E $\left.=-0.5 \mathrm{~V}\right)$ is linear, as shown in Fig. 2. After fitting, the electron transfer numbers for $\mathrm{MnOOH} / \mathrm{Mn}(\mathrm{OH})_{4}, \mathrm{MnO}_{2}$, $\mathrm{Mn}_{2} \mathrm{O}_{3}$, and $\mathrm{Mn}_{3} \mathrm{O}_{4} / \mathrm{Mn}_{2} \mathrm{O}_{3}$ were calculated to be 3.5, 3.5, 3.6, and 3.5, respectively, suggesting that a four-electron transfer is the dominant process for carbon-supported $\mathrm{MnO}_{x}$. For comparison, the electron transfer number for Vulcan ${ }^{\circledR} \mathrm{XC}-72$ carbon is only 2.1, suggesting that a two-electron process is dominant with $\mathrm{HO}_{2}{ }^{-}$as the main product.

\subsection{Influence of catalyst thickness on $\mathrm{HO}_{2}{ }^{-}$yields}

To elucidate the apparent four-electron transfer process, we investigated the changes in the $\mathrm{HO}_{2}{ }^{-}$yield with varying catalyst thickness: if $\mathrm{HO}_{2}{ }^{-}$is the intermediate in the $\mathrm{ORR}$, the $\mathrm{HO}_{2}{ }^{-}$yield should decrease with increasing catalyst thickness, because the $\mathrm{HO}_{2}{ }^{-}$species has a greater probability of chemically decomposing to form $\mathrm{O}_{2}$ [10,13]; otherwise, the ORR should be a direct four-electron transfer process with negligible $\mathrm{HO}_{2}{ }^{-}$production $[14,15]$.

To avoid any changes in the surface manganese valence, fresh $\mathrm{MnO}_{x}$ samples were used for the RRDE tests. The RRDE measurements were performed in an $\mathrm{O}_{2}$-saturated $0.1 \mathrm{~mol} / \mathrm{L}$ $\mathrm{NaOH}$ electrolyte. The measured disk currents are shown in Fig. 3(a). The $\mathrm{HO}_{2}{ }^{-}$yield can be calculated from Eq. (2):

$$
X_{\text {HO2 }^{-}}=\left(2 i_{\text {ring }} / N\right) /\left(i_{\text {disk }}+i_{\text {ring }} / N\right)
$$

where $i_{\text {ring }}$ and $i_{\text {disk }}$ are the ring current and disk current, re- spectively, and $N$ is the collecting efficiency of the RRDE $(N=$ 0.38 after calibration). The calculated $\mathrm{HO}_{2}^{-}$yield $\left(\mathrm{XHO2}^{-}\right)$is shown in Fig. 3(b). To enable a clear comparison, the $\mathrm{HO}_{2}{ }^{-}$ yields (@-0.4 V vs MMO) for different electrocatalysts are listed in Table 1. It can be seen that for all catalysts, as the catalyst loading increases from 3.75 to $30 \mu \mathrm{g}$, the quasi-limiting current increases, but the ORR onset potential remains almost constant. For the $\mathrm{MnOOH} / \mathrm{Mn}(\mathrm{OH})_{4}$ sample, with a catalyst loading of $3.75 \mu \mathrm{g}$, the maximum $\mathrm{X}_{\mathrm{HO} 2}{ }^{-}$is $87.4 \%$, indicating a dominant two-electron process. The $\mathrm{HO}_{2}{ }^{-}$yield sharply decreases with increasing catalyst loading. As the catalyst loading increases to $30 \mu \mathrm{g}$, the $\mathrm{HO}_{2}{ }^{-}$yield decreases to around $21 \%$. For the $\mathrm{MnO}_{2}$ sample, $\mathrm{X}_{\mathrm{HO} 2}{ }^{-}$decreases from $26 \%$ to $6.6 \%$ with increasing catalyst loading from 3.75 to $30 \mu \mathrm{g}$, suggesting a four-electron process at high catalyst loading. These results clearly show that $\mathrm{O}_{2}$ is first reduced to $\mathrm{HO}_{2}{ }^{-}$, which is then reduced or chemically decomposes in a thick catalyst layer, therefore the $\mathrm{HO}_{2}^{-}$yield detected by the Pt ring electrode decreases with increasing catalyst layer thickness. Bonakdarpour et al. [13] investigated the ORR at Fe/N/C electrodes and made similar observations, i.e., the $\mathrm{HO}_{2}^{-}$yield decreased from $60 \%-80 \%$ to $2 \%-15 \%$ as the catalyst layer increased from 40 $\mu \mathrm{g} / \mathrm{cm}^{2}$ to $800 \mu \mathrm{g} / \mathrm{cm}^{2}$.

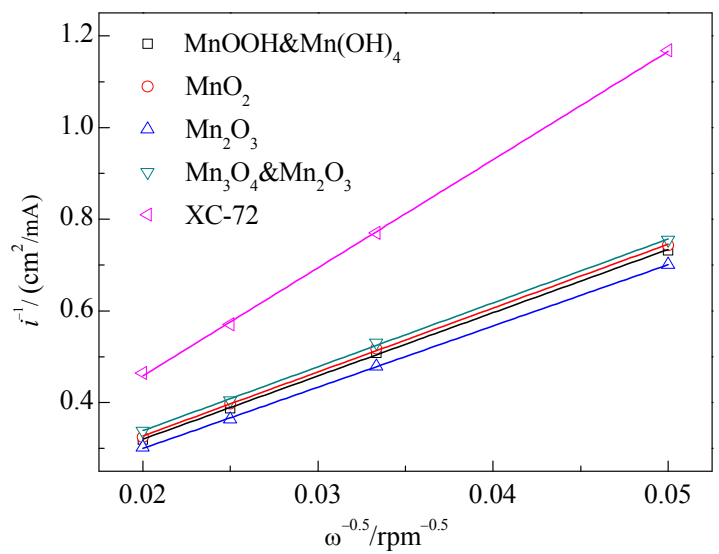

Fig. 2. Koutecky-Levich plots of $\mathrm{ORR}$ on $\mathrm{MnO}_{x}+\mathrm{C}$ catalysts (derived from Fig. 1). 

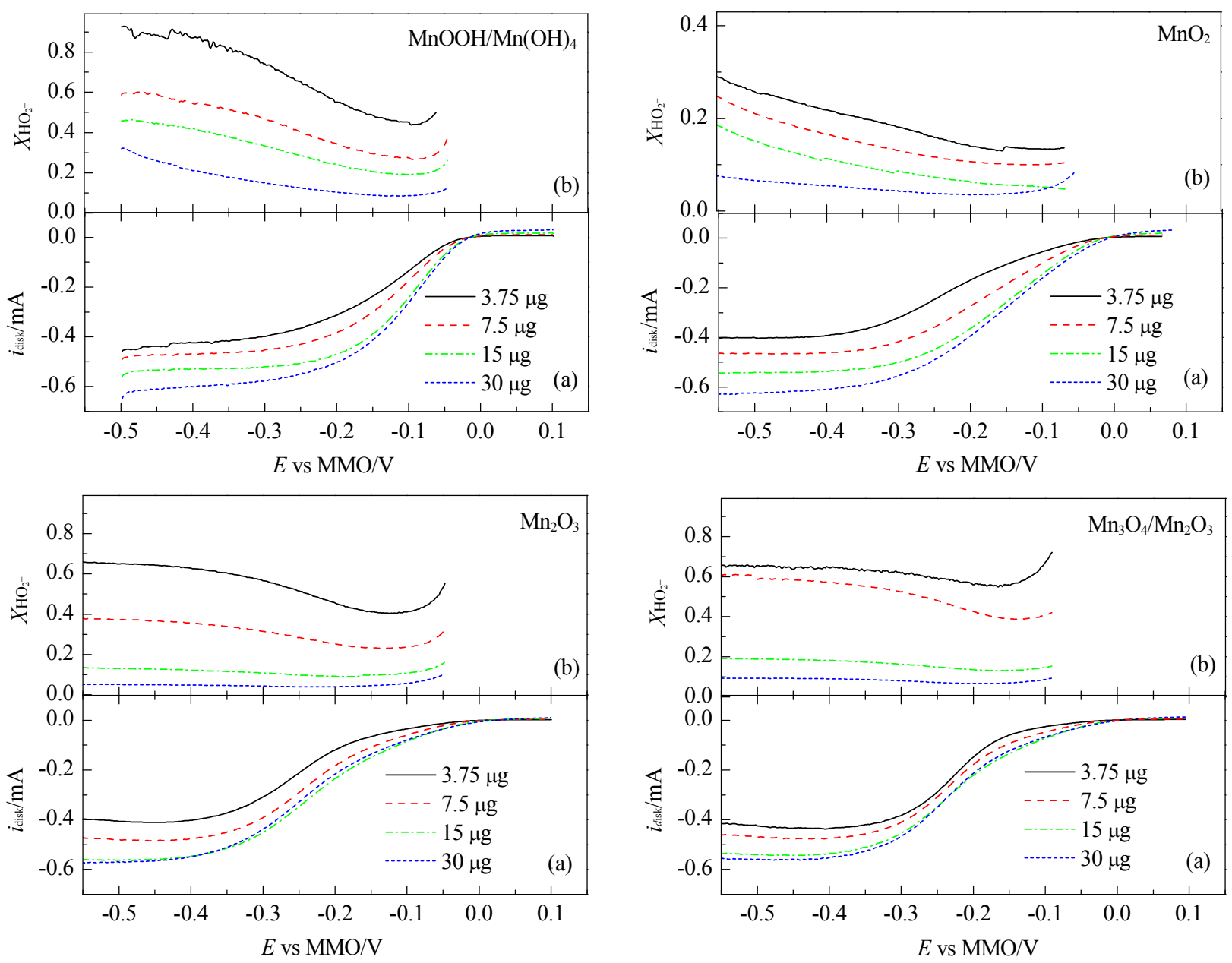

Fig. 3. Disk currents (a) and $\mathrm{HO}_{2}{ }^{-}$yields (b) on $\mathrm{MnO}_{x} / \mathrm{C}$ catalysts with different catalyst loadings at rotation rate of $1600 \mathrm{rpm}$ and scanning rate of 10 $\mathrm{mV} / \mathrm{s}$. Collection efficiency $N=0.38$; ring potential was maintained at $E_{\text {ring }}=0.2 \mathrm{~V}$.

\subsection{Determination of ORR pathways at carbon-supported $\mathrm{MnO}_{x}$ catalysts}

\subsubsection{Calculation of TOF (HODR)}

To further clarify whether chemical decomposition or electrochemical reduction of the generated $\mathrm{HO}_{2}{ }^{-}$intermediate is dominant, we calculated and compared the TOFs of the HORR and HODR. The HODR TOF was calculated as described in the Experimental section. The difference between the ORR limiting current ( $i_{\text {lim,ORR }}$ ), measured in $\mathrm{O}_{2}$-saturated $1 \mathrm{~mol} / \mathrm{L} \mathrm{NaOH}$, and the time-dependent limiting current of $i_{\text {lim, }}$ measured in $\mathrm{O}_{2}$-saturated $1 \mathrm{~mol} / \mathrm{L} \mathrm{NaOH}+0.85 \mathrm{mmol} / \mathrm{L} \mathrm{H}_{2} \mathrm{O}_{2}$, gives the limiting current for $\mathrm{HO}_{2}{ }^{-}$electrochemical reduction ( $i_{\text {lim,HORR }}$ ) as $i_{\mathrm{lim}}-i_{\mathrm{lim}, \mathrm{ORR}}$. The changes in $i_{\mathrm{lim}, \mathrm{HORR}}$ with time can be used to

\section{Table 1}

$\mathrm{HO}_{2}^{-}$yields for different electrocatalysts (@- $0.4 \mathrm{~V}$ vs MMO).

\begin{tabular}{lcccc}
\hline $\begin{array}{l}\text { Catalyst mass } \\
(\mu \mathrm{g})\end{array}$ & \multicolumn{4}{c}{$\mathrm{HO}_{2}{ }^{-}$yield (\%) } \\
\cline { 2 - 5 } & $\mathrm{Mn}(\mathrm{OH})_{4}$ & $\mathrm{MnO}_{2}$ & $\mathrm{Mn}_{2} \mathrm{O}_{3}$ & $\mathrm{Mn}_{3} \mathrm{O}_{4} / \mathrm{Mn}_{2} \mathrm{O}_{3}$ \\
\hline 3.75 & 87.4 & 26.2 & 65.3 & 65.4 \\
7.5 & 55.0 & 21.4 & 37.4 & 58.7 \\
15.0 & 41.8 & 15.3 & 13.2 & 19.0 \\
30.0 & 21.3 & 6.6 & 4.9 & 9.7 \\
\hline
\end{tabular}

calculate the TOF of the HODR at the $\mathrm{MnO}_{x}$ surface, as described below [10]. It should be noted that the $\mathrm{NaOH}$ solution was saturated with $\mathrm{O}_{2}$ in measuring the $\mathrm{H}_{2} \mathrm{O}_{2}$ reduction current, to eliminate the influence of $\mathrm{O}_{2}$ on $\mathrm{HO}_{2}{ }^{-}$chemical decomposition. It should also be mentioned that the calculation of TOF HODR was

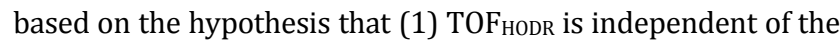
$\mathrm{HO}_{2}{ }^{-}$concentration and (2) all the $\mathrm{MnO}_{x}$ takes part in the reaction. Theoretically, the HORR limiting current can be expressed as

$$
i_{\mathrm{lim}, \mathrm{HORR}}=2 \mathrm{FD}_{2} \mathrm{C2}^{*} / \delta
$$

where $D_{2}$ is the diffusion coefficient of $\mathrm{HO}_{2}{ }^{-}$in the electrolyte, $\mathrm{C}_{2}{ }^{*}$ is the bulk concentration of $\mathrm{HO}_{2}{ }^{-}$, and $\delta$ is the diffusion layer thickness of the electrode at a rotating speed of $1600 \mathrm{rpm}$.

The HODR is approximately first order at low $\mathrm{HO}_{2}{ }^{-}$concentrations, therefore the reaction rate can be expressed as

$$
\nu_{\text {HODR }}=-\mathrm{d} c 2^{*} / \mathrm{d} t=k \text { HODRC } 2^{*}
$$

where $k_{\text {HODR }}$ is the apparent reaction rate constant of the HODR, which is related to the amount of catalyst in the electrolyte. Combining Eqs. (3) and (4), the relationship between $i_{\text {lim,HORR }}$ and $k_{\text {HODR }}$ is expressed as

$$
k_{\text {HODR }}=-\ln (10) \operatorname{dlog}\left(i_{\text {lim,HORR }}\right) / d t
$$

The changes in $\log \left(i_{\text {lim,HORR }}\right)$ with time are shown in Fig. 4, 


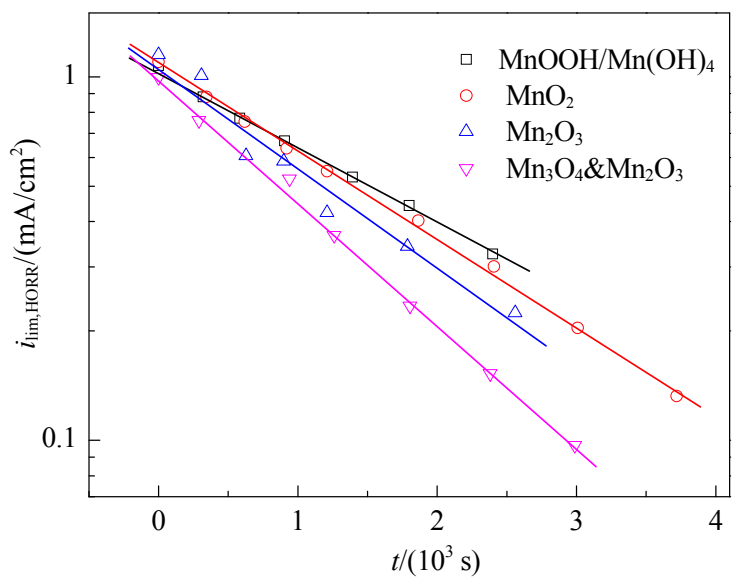

Fig. 4. Time-dependent plots of $\mathrm{HO}_{2}^{-}$reduction current density (proportional to bulk $\mathrm{HO}_{2}{ }^{-}$concentration) in $1 \mathrm{~mol} / \mathrm{L} \mathrm{NaOH}$ solution.

which is fitted linearly, indicating that the HODR is a first-order reaction, as supposed. If the catalyst amount added to the electrolyte is the same for different samples, the slopes of the lines reflect the HODR rates for different $\mathrm{MnO}_{x}$ catalysts, i.e., $\mathrm{Mn}_{3} \mathrm{O}_{4} / \mathrm{Mn}_{2} \mathrm{O}_{3}>\mathrm{Mn}_{2} \mathrm{O}_{3}>\mathrm{MnO}_{2}>\mathrm{MnOOH} / \mathrm{Mn}(\mathrm{OH})_{4}$.

Furthermore, $k_{\text {HODR }}$ is related to the TOF by Eq. (6) [10]:

$$
\mathrm{TOF}_{\text {HODR }}=k_{\text {HODR }} V c_{2}{ }^{*} M_{\mathrm{Mn}} /(\mathrm{mW})
$$

where $V$ is the volume of the electrolyte, $m$ is the mass of $\mathrm{MnO}_{x_{1}}$ $\mathrm{C}_{2}{ }^{*}$ is the bulk concentration of $\mathrm{HO}_{2}^{-}, W$ is the mass percentage of manganese in $\mathrm{MnO}_{x}$, and $M_{\mathrm{Mn}}$ is the atomic weight of manganese $(54.95 \mathrm{~g} / \mathrm{mol})$. The calculated results are listed in Table 2.

\subsubsection{Calculation of TOF (HORR)}

The HORR polarization curves for the $\mathrm{MnO}_{x}$ catalysts were measured in a $\mathrm{N}_{2}$-saturated $0.85 \mathrm{mmol} / \mathrm{L} \mathrm{H}_{2} \mathrm{O}_{2}+1 \mathrm{~mol} / \mathrm{L} \mathrm{NaOH}$ electrolyte and are shown in Fig. 5(a). To eliminate the influence of mass transport, the kinetic HORR currents were derived from Fig. 5(a) according to [12]:

$$
1 / i_{\lim }=1 / i+1 / i_{k}
$$

The obtained Tafel plots are shown in Fig. 5(b). It can be seen that reduction currents are detected for the four $\mathrm{MnO}_{x}$ catalysts and the onset potentials are around $-0.05 \mathrm{~V}$. $\mathrm{Mn}_{2} \mathrm{O}_{3}$ and $\mathrm{MnO}_{2}$ have the most positive and the most negative half-wave potential, respectively. The limiting currents are in the range -0.06 to $-0.10 \mathrm{~mA}$. For comparison, the theoretical limiting current of the HORR was calculated according to the Koutecky-Levich equation; at around $1.6 \mathrm{~mA} / \mathrm{cm}^{2}$, it is ca. $0.31 \mathrm{~mA}$ for an electrode of $\phi 5 \mathrm{~mm}$, with a diffusion coefficient of $\mathrm{HO}_{2}{ }^{-}$in $1 \mathrm{~mol} / \mathrm{L}$ $\mathrm{NaOH}$ of $1.3 \times 10^{-9} \mathrm{~m}^{2} / \mathrm{s}$, electrolyte viscosity of $1 \times 10^{-4} \mathrm{~m}^{2} / \mathrm{s}$, and electrode rotating speed of $1600 \mathrm{rpm}$. The much lower experimental limiting current compared with the calculated

Table 2

Reaction rates of $\mathrm{HO}_{2}{ }^{-}$electroreduction and decomposition.

\begin{tabular}{lcc}
\hline Catalyst & TOF $_{\text {HODR }}\left(10^{-2} \mathrm{~s}^{-1}\right)$ & TOF $_{\text {HORR }}$ at $-0.12 \mathrm{~V}\left(10^{-4} \mathrm{~s}^{-1}\right)$ \\
\hline $\mathrm{MnOOH} \& \mathrm{Mn}(\mathrm{OH})_{4}$ & 2.41 & 4.36 \\
$\mathrm{MnO}_{2}$ & 2.74 & 3.35 \\
$\mathrm{Mn}_{2} \mathrm{O}_{3}$ & 2.87 & 5.03 \\
$\mathrm{Mn}_{3} \mathrm{O}_{4} \& \mathrm{Mn}_{2} \mathrm{O}_{3}$ & 3.39 & 3.96 \\
\hline
\end{tabular}
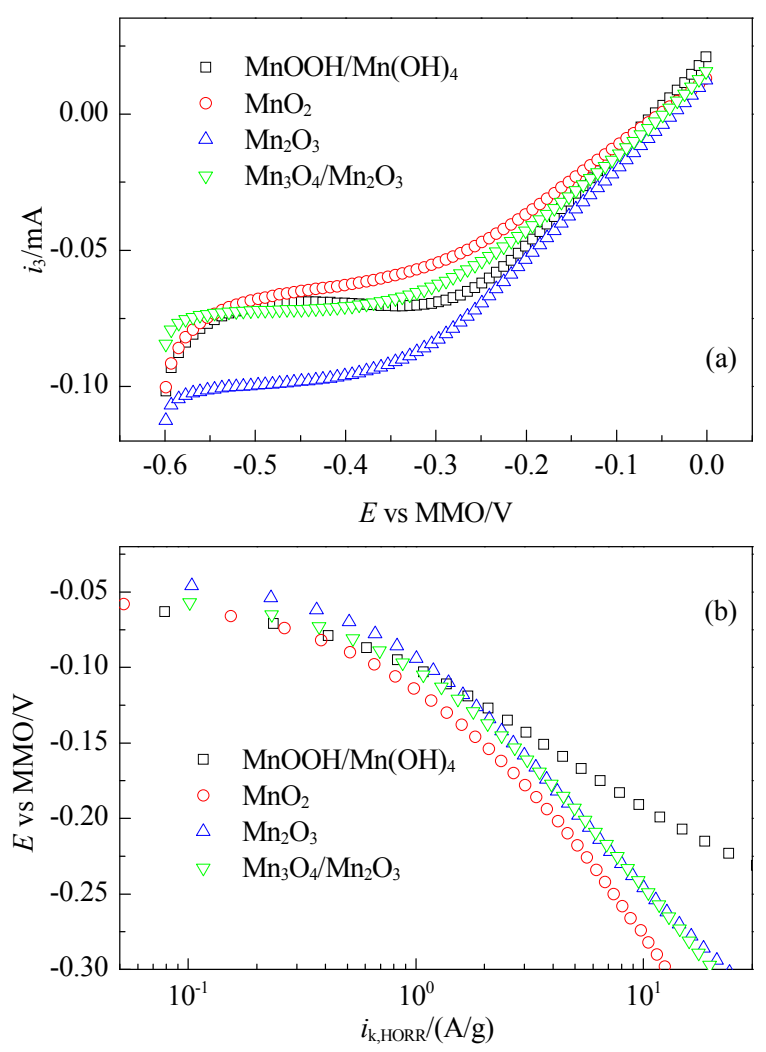

Fig. 5. (a) Polarization curves for $\mathrm{HORR}$ with $\mathrm{MnO}_{x}$ catalysts in $\mathrm{N}_{2}$-saturated $0.85 \mathrm{mmol} / \mathrm{L} \mathrm{H}_{2} \mathrm{O}_{2}+1 \mathrm{~mol} / \mathrm{L} \mathrm{NaOH}$ electrolyte and (b) derived Tafel plots for HORR (currents are normalized to mass of $\mathrm{MnO}_{x}$ catalyst). Electrode rotating speed: $1600 \mathrm{rpm}$, scanning rate: $10 \mathrm{mV} / \mathrm{s}$.

value shows that only some $\mathrm{HO}_{2}{ }^{-}$is electrochemically reduced, and some is chemically decomposed to form $\mathrm{O}_{2}$, which is either electrochemically reduced or released to the atmosphere. In the following calculation, it is assumed that the limiting current results entirely from reduction of $\mathrm{HO}_{2}^{-}$, to obtain the maximum TOF of the HORR. The TOF of the HORR is calculated as [10]

$$
\mathrm{TOF}_{\mathrm{HORR}}=i_{\mathrm{k}, \mathrm{HORR}} M_{\mathrm{Mn}} /(n F W)
$$

where $i_{\mathrm{k}, \mathrm{HORR}}$ is the kinetic current of the $\mathrm{HO}_{2}{ }^{-}$electrochemical reduction, $n$ is the electron transfer number, and $F, W$, and $M_{\mathrm{Mn}}$ have the same meanings as in Eqs. (3) and (6). The values at $-0.12 \mathrm{~V}$ are listed in Table 2 for comparison.

From Table 2, it is clearly seen that for the four $\mathrm{MnO}_{x}$ catalysts, the TOF for the HODR is two orders of magnitude higher than that for the HORR, indicating that the intermediate $\mathrm{HO}_{2}{ }^{-}$ mainly undergoes subsequent chemical decomposition. These $\mathrm{MnO}_{x}$ samples have similar morphologies; one reason for the better ORR activities of $\mathrm{Mn}_{2} \mathrm{O}_{3}$ and $\mathrm{Mn}_{3} \mathrm{O}_{4} / \mathrm{Mn}_{2} \mathrm{O}_{3}$ is probably faster chemical decomposition of the $\mathrm{HO}_{2}{ }^{-}$intermediate on these catalysts.

\section{Conclusions}

A comparison of the TOFs of the HODR and HORR showed that although apparent four-electron transfer processes were observed by measuring the $\mathrm{HO}_{2}{ }^{-}$yield via the $\mathrm{RRDE}$ technique, the real ORR pathway involves a two-electron transfer process to generate $\mathrm{HO}_{2}-$, with subsequent chemical decomposition. 


\title{
Graphical Abstract
}

Chin. J. Catal., 2015, 36: 175-180 doi: 10.1016/S1872-2067(14)60249-7

\section{Elucidation on oxygen reduction reaction pathway on carbon-supported manganese oxides}

Luhua Jiang*, Qiwen Tang, Jing Liu, Gongquan Sun*

Dalian Institute of Chemical Physics, Chinese Academy of Sciences;

University of Chinese Academy of Sciences

The real ORR pathway behind the apparent four-electron process on carbon-supported manganese oxides was shown to be a two-electron transfer reaction followed by hydroperoxide disproportionation.

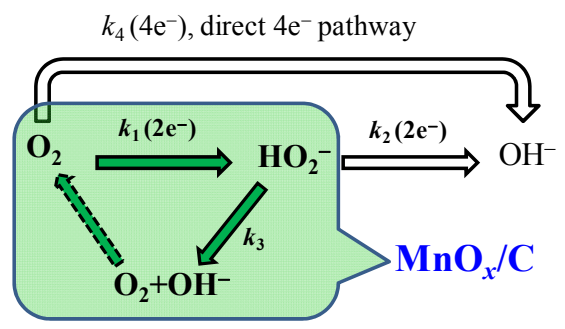

These results are expected to help us to understand the intrinsic catalytic behavior of carbon-supported transition-metal oxides for the ORR in alkaline electrolytes.

\section{References}

[1] Spendelow J S, Wieckowski A. Phys Chem Chem Phys, 2007, 9: 2654

[2] Yeager E. Electrochim Acta, 1984, 29: 1527

[3] Zhang J, Tang S H, Liao L Y, Yu W F. Chin J Catal (张浩, 唐水花, 廖 龙渝, 郁卫飞. 催化学报), 2013, 34: 1051

[4] Liu J, Jiang L H, Tang Q W, Zhang B S, Su D S, Wang S L, Sun G Q. ChemSusChem, 2012, 5: 2315

[5] Liu J, Jiang L H, Zhang B S, Jin J T, Su D S, Wang S L, Sun G Q. ACS Catal, 2014, 4: 2998

[6] Mao L Q, Zhang D, Sotomura T, Nakatsu K, Koshiba N, Ohsaka T.
Electrochim Acta, 2003, 48: 1015

[7] Ohsaka T, Mao L Q, Arihara K, Sotomura T. Electrochem Commun, 2004, 6: 273

[8] Tang Q W, Jiang L H, Liu J, Wang S L, Sun G Q. ACS Catal, 2014, 4: 457

[9] Paulus U A, Schmidt T J, Gasteiger H A, Behm R J. J Electroanal Chem, 2001, 495: 134

[10] Jaouen F, Dodelet J P. J Phys Chem C, 2009, 113: 15422

[11] Paliteiro C, Hamnett A, Goodenough J B. J Electroanal Chem, 1987, 233: 147

[12] Bard A J, Faulkner L R. Electrochemical Methods - Fundamentals and Applications. New York: John Wiley \& Sons, 1980. 237

[13] Bonakdarpour A, Lefevre M, Yang R Z, Jaouen F, Dahn T, Dodelet J P, Dahn J R. Electrochem Solid-State Lett, 2008, 11: B105

[14] Jaouen F. J Phys Chem C, 2009, 113: 15433

[15] Herrmann I, Koslowski U I, Radnik J, Fiechter S, Bogdanoff P. ECS Trans, 2008, 13(17): 143

\section{碳载氧化锰表面氧还原反应路径研究}

\author{
姜鲁华 ${ }^{\mathrm{a},}$, 唐琪雯 ${ }^{\mathrm{a}, \mathrm{b}}$, 刘 静 ${ }^{\mathrm{a}, \mathrm{b}}$, 孙公权 ${ }^{\mathrm{a}, \#}$ \\ ${ }^{\mathrm{a}}$ 中国科学院大连化学物理研究所, 大连洁净能源国家实验室(筹), 辽宁大连116023 \\ b中国科学院大学, 北京 100049
}

摘要: 氧还原反应(ORR)是一个复杂的过程, 尤其在碱性电解液中, 炭载型催化剂表面的ORR路径尤为复杂, 因为碳本身可以催化 ORR以二电子转移过程发生, 产生过氧化氢, 继而过氧化氢或者发生化学分解生成氧气(HODR), 或者发生电化学还原生成 $\mathrm{OH}^{-}$ (HORR). 本文详细研究了 ORR在常用氧化锰催化剂表面的反应路径. 通过比较HODR和HORR的转换频率发现, 尽管利用旋转环 盘电极方法得到的表观电子转移数接近 4 , 真实的ORR主要是 2 电子过程, 反应生成的过氧化氢继而大部分发生化学分解生成氧 气. 该结果有助于理解碱性电解质中炭载型过渡金属氧化物电催化剂对ORR的催化行为.

关键词: 氧还原反应路径; 碱性电解质; 碳载氧化锰电催化剂

收稿日期: 2014-09-30. 接受日期：2014-11-10. 出版日期: 2015-02-20.

*通讯联系人. 电话: (0411)84379603; 传真: (0411)84379063; 电子信箱: sunshine@dicp.ac.cn

\#通讯联系人. 电话: (0411)84379603; 传真: (0411)84379063; 电子信箱: gqsun@dicp.ac.cn

基金来源：中国科学院战略性先导科技专项(XDA09030104); 国家重点基础研究发展计划(973计划, 2012CB215500); 国家自然 科学基金(21033009); 中国科学院“百人计划”.

本文的英文电子版由Elsevier出版社在ScienceDirect上出版(http://www.sciencedirect.com/science/journal/18722067). 